THE CRITICS DEBATE

General Editor: Michael Scott 
The Critics Debate

General Editor: Michael Scott

Published titles:

Sons and Lovers Geoffrey Harvey

Bleak House Jeremy Hawthorn

The Canterbury Tales Alcuin Blamires

Tess of the d'Urbervilles Terence Wright

Hamlet Michael Hattaway

The Waste Land and Ash Wednesday

Arnold P.Hinchliffe

Paradise Lost Margarita Stocker

King Lear Ann Thompson

Othello Peter Davison

Gulliver's Travels Brian Tippett

The Winter's Tale Bill Overton

Blake: Songs of Innocence and Experience

David W. Lindsay

Measure for Measure T. F. Wharton 


\section{BLAKE: SONGS OF INNOCENCE AND EXPERIENCE}

David W. Lindsay

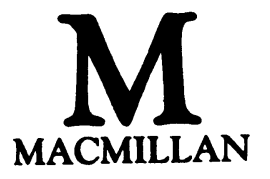


(C) David W. Lindsay 1989

Softcover reprint of the hardcover 1st edition 1989 978-0-333-44434-4

All rights reserved. No reproduction, copy or transmission of this publication may be made without written permission.

No paragraph of this publication may be reproduced, copied or transmitted save with written permission or in accordance with the provisions of the Copyright Act 1956 (as amended), or under the terms of any licence permitting limited copying issued by the Copyright Licensing Agency, 33-4 Alfred Place, London WC1E 7DP.

Any person who does any unauthorised act in relation to this publication may be liable to criminal prosecution and civil claims for damages.

First published 1989

Published by

MACMILLAN EDUCATION LTD

Houndmills, Basingstoke, Hampshire RG21 2XS

and London

Companies and representatives

throughout the world

British Library Cataloguing in Publication Data

Lindsay, David W.

Songs of innocence and experience. -

(The Critics debate).

1. Poetry in English. Blake, William, 1757-

1827. Songs of innocence \& Songs of experience - Critical studies

I. Title II. Blake, William, 1757-1827.

Songs of innocence \& Songs of experience

$821^{\prime} .7$

ISBN 978-0-333-44435-1 ISBN 978-1-349-20005-4 (eBook)

DOI 10.1007/978-1-349-20005-4 
For Cora 
Contents

General Editor's Preface

Author's Preface

Introduction

Part One: Survey

Defining the text

Antecedents of Innocence

Reading the designs

Voices of Innocence

'The Chimney Sweeper'

Transition and system

Counterparts

Voices of Experience

A trilogy

Part Two: Appraisal

Novitiate: 'Holy Thursday'

Eden: 'The Ecchoing Green'

Generation: 'The Little Girl Lost' and

'The Little Girl Found'

66

Prophecy: 'The Tyger' and 'The Fly'

71

Scripture: 'The Human Abstract'

76

Redemption: 'To Tirzah'

References

Index to Poems

89

Index to Critics 


\section{General Editor's Preface}

Over the last few years the practice of literary criticism has become hotly debated. Methods developed earlier in the century and before have been attacked and the word 'crisis' has been drawn upon to describe the present condition of English Studies. That such a debate is taking place is a sign of the subject discipline's health. Some would hold that the situation necessitates a radical alternative approach which naturally implies a 'crisis situation'. Others would respond that to employ such terms is to precipitate or construct a false position. The debate continues but it is not the first. 'New Criticism' acquired its title because it attempted something fresh, calling into question certain practices of the past. Yet the practices it attacked were not entirely lost or negated by the new critics. One factor becomes clear: English Studies is a pluralistic discipline.

What are students coming to advanced work in English for the first time to make of all this debate and controversy? They are in danger of being overwhelmed by the cross-currents of critical approaches as they take up their study of literature. The purpose of this series is to help delineate various critical approaches to specific literary texts. Its authors are from a variety of critical schools and have approached their task in a flexible manner. Their aim is to help the reader come to terms with the variety of criticism and to introduce him or her to further reading on the subject and to a fuller evaluation of a particular text by illustrating the way it has been approached in a number of contexts. In the first part of the book a critical survey is given of some of the major ways the text has been appraised. This is done sometimes in a thematic manner, sometimes according to various 'schools' or 'approaches'. In the second part the authors provide their own appraisals of the text from their stated critical standpoint, allowing the reader the knowledge of their own particular approaches from which their views may in turn be evaluated. The series therein hopes to introduce and to elucidate criticism of authors and texts being studied and to encourage participation as the critics debate. 


\section{Author's Preface}

The structural principles governing this survey of Blake criticism should be clear from the table of contents; but some further explanation may be found helpful. The Introduction describes how a Blakean engraved book was created, and considers the implications of this process. The first section of Part One assesses the advantages and disadvantages of the various printed texts. The next four sections of Part One examine a range of critical approaches, with particular reference to Songs of Innocence. The last four sections of Part One examine a further range of critical approaches, with particular reference to Songs of Experience. Part Two traces the evolution of Songs of Innocence and Experience in the context of Blake's other writings, and gives closer attention to eight poems. The list of references identifies the critical works mentioned, and offers suggestions for further reading.

Alan Bellringer, Tony Brown, Tom Corns, John Eadie, Peter Field, Ian Gregson, Chris Jones, Margaret Locherbie-Cameron, Brian Mastin, Mark Sinfield and Bill Tydeman have assisted me in a variety of ways. I am also grateful to Pat Pritchard and Joyce Williams, who typed the manuscript, and to the library staff of the University College of North Wales. My greatest debt, as always, is to my wife.

Bangor 1988

David W. Lindsay 